\title{
The Impact of Organizational Culture on Job Satisfaction, Employess Commitment and Turn over Intention
}

\author{
BZU Bahadur Sub Campus Layyah, Punjab, Pakistan \\ *Corresponding Author: salman_mba@outlook.com
}

Salman Habib*, Saira Aslam, Amjad Hussain, Sana Yasmeen, Muhammad Ibrahim

\section{Copyright (C) 2014 Horizon Research Publishing All rights reserved}

\begin{abstract}
The purpose of the present research was to explore the impact of organizational culture on the job satisfaction, employees' commitment and the retention of the employees in the organization. The research was based on primary data, and this research was conducted on the employee's working in different organizations within territory of Multan region, Punjab, Pakistan. Data was collected through questionnaire consisting of 24 questions; the sample consisted of 235 employees of different Organizations (MCB Layyah, U micro Finance Bank Layyah, Layyah Sugar Mill, Thermal Power Plant Muzaffar Garh, and NRSP DG Khan). The Correlation analysis test was applied through SPSS to find out the results of research. Results indicated that nature of organization significantly effects on Job Satisfaction and turnover intentions. So the findings of research proved that organizational culture is important element which highly influences the employee commitment, job satisfaction and retention.
\end{abstract}

Keywords Organizational Culture, Employees, Commitment, Employees, Retention, Job Satisfaction

\section{Introduction}

It is very necessary for an organization to establish an organizational culture to maintain its position in market. The organizational culture must be developed which may provide support to an organization and bring continuous improvement. The culture of an organization is very important for the progress of an organization because it impacts on employee commitment and their retention as well. If the culture of an organization is flexible it will provide such working environment to employees in which they may work easily and independently without feeling any burden. Every organization wants employee commitment because it is very important for an organizational effectiveness. If the employees understand the organizational culture properly so that there may be improvement in their performance the reason is that the employee's performance is the base of an organization.
Most of the researched have been conducted worldwide that has been provided the significant importance to organizational culture that impact on employee commitment and retention.

Organizational culture is a set of different value system which can help an organization to run itself and run a successful business Schhneider (1983). Organizational culture helps employees to understand the functioning of the organizations by sharing its norms, values and rules and regulation of organization (Deshpande and Webster, 1989). According to(Lok\& Crawford, 2004) organizational culture has remarkable effect on employee's commitment and performance. If the employees of the organization have more understanding with the organizational culture they will have more job Satisfaction (Chang and Lee, 2007). O'Reilly and Chatman's (1996) defined organization culture is a setup of behavior, attitude and values. According to Hertzberg (1959) in his study job satisfaction is a part of employee job, if it affect positively it motivate employee to job satisfaction otherwise it leads to job dissatisfaction. Job satisfaction is emotional ability of employee related to positive and negative aspect of its job experiences Locke (1969). Environment of organization and employee's personal traits can influence its job satisfaction Seasohore and Taber (1975). A committed employee is the person who stay with the organization in tough condition and try to fulfill the organizational goals, Meyer and Allen (1997), cited in Rashid, Sambasivan\&Johari 2003. According to Silverthorne (2004) organizational culture and Commitment has strong relationship, but organizations with negative organizational culture faces lack of employee commitment.

Continuance commitment makes sure that employee will not quit the organization and will not response to dissatisfaction and make sure that they remain with the organization (Appelbaum, et al. 2004). job satisfaction has a very strong effect and it is almost inversely associated with employee's intention to leave or stay an organization(Egan,Yang\&Bartlett,2004; Lambert, Hogan \& Barton,2001; MacIntosh Doherty, 2010; Schwepker, 2001; Silverthorne, 2004).According to the Heery Edmund and Noon Mike, 2001employees' retention is the ability to keep 
your employees in the organization and find solution to avoid losing your valuable staff.

According to Sheridan(1992) this is confirmed that organizational culture have a strong impact on employee's retention rates.

Despites of so much researches and studies there is contradiction about the impact of organizational culture on employee commitment and turnover intention because it provides no such reasonable relationship between organizational culture and employee performance, the various studies based on empirical evidence have come as contradictory results about the impact of organizational culture on employee commitment and retention. As there is much contradiction in results the question is that either organizational culture enhances the employee commitment or not. So there is further need to research to cover this gap mostly researches have been conducted in developing countries.

This study focuses on the Impact of Organizational Culture on Job Satisfaction, Employees Commitment and Turnover Intention. In addition, it will get us introduce to the main problems arises from the Inefficient Organizational culture which leads employees to quit their jobs. The study will not only enable us to have insight into the impact of Organizational culture on the employees commitment, job satisfaction and causes of turnover intentions but will also provide help in finding the solutions to these problems. This research will also suggest ways to overcome the problems and improve the current practices.

\section{Objectives of the Research}

1. Main objective is to explore the impact of organizational culture on organization performance

2. Find out the impact of organizational culture on employees performance

3. To find out whether organizational culture impact satisfaction and retention level

This research examines the effect of the organizational culture in employee commitment and retention if the organizational culture is positive and flexible then it will enhance the performance of the employees and their commitment. It helps in achievement of the organizational goals. If organizational culture is negative and weak then it will minimize the performance of the employees and will become hindrance in achievement of goal of organization, it tells how an organization can built a better culture that will increase the employee commitment and involvement.

\section{Literature Review}

\subsection{Organizational Culture}

According to (Hofstede, 2001) "Organizational culture is that set of beliefs, values, work styles and relationships that distinguish one organization from another". "Organizational culture has been explored as it relates to job satisfaction, organizational commitment, productivity, and turnover intention (Lund, 2003; Sims, 2002)". According to Pettigrew (1979), organizational culture of any organization mostly based on psychological affects which help researchers how employees think about the organization, and how organizational culture effects their decisions. He also believes that different level of organizational culture based on the different believes, values, ritual, and past stories of organizations. According to Robbins \&Sanghi (2007), organizational Culture is a system of common values which we can estimate that employees accept the similar organization culture even with different background within the organization. Tichy (1982), described that organizational culture "normative glue" which means organizational culture hold all organizational process together. Organizational culture influenced the internal organizational policies, it's also effects the employee's commitment towards the goals and values of the organization, it increases the employees willing to puts its all efforts to satisfy the customer so he must be willing to return to the company for re-purchase (Bolton et al, 2000). Organizational Culture affects the different people differently because the way in which they consciously and subconsciously think and, make decisions it's all have because of what they perceive and what they feel and act upon it after feeling (Lok\&Crawford, 2004; Hansen \&Wernerfelt 1989; Schein, 1990). According to the Jaegar\&Kanungo(1990)management behavior and trusty environment is possible to maintain and also affected by the uncertainty in economic system, high individualism these things impose negative impact on the performance of the employees. If organizational culture creates problems like difficulties in changes, create barriers to diversity then Cultures of that organization is liability for that organization (Robbins, 2009).

H1: Strong Organization Culture has positive impact on employee's performance.

\subsubsection{Attention to Detail}

The degree to which employees is expected to exhibit precision, analysis, and attention to detail. Organizational culture based on employee's culture, and culture developed by the employees of organization. Every employee has different values, culture, personality, and traits according to its own values which are given. Then they work according to organization culture which is set by the organization. So there is positive impact of employee and organizational culture according to their customs. It tells all the detail about culture and then evaluated the whole organization which gives positive results.

\subsubsection{Outcome Orientation}

The degree to which managers focuses on outcomes of the results and they do not pay attention that how those outcomes have been achieved. They do not focus on the ways methods in cause of that outcome. They only keep the 
concern with the final results.

\subsubsection{People Orientation}

When the management take the decision in the organization it impacts on employees, working in that organization negatively and positively. If the decision taken by the management in the favor of the organization as well as in the favor of the organization peoples then it would impact positively. And if they take such decisions which are not in the favor of organizational people then it will impact negatively.

\subsubsection{Team Orientation}

Degree to which the teams form to all works and to perform the work of the organization because through the team the goals can be achieved successfully rather than working as an individually.

\subsubsection{Aggressiveness}

The degree to which employees of organization is aggressive and competitive rather than co-operative. In this case mostly employees compete with each other for rewards and there is no unity among them to work for achievements of organizational goals.

\subsubsection{Stability}

It is the degree at which gradual changes occur where the organizational decisions and actions emphasis maintaining the status quo. The organizational culture remains stable and change at slow rate that do not brings huge change in it. So any decision which is taken regarding taking any action remains maintain.

\subsubsection{Innovation and Risk Taking}

It is a degree in which employees are encouraged to be innovative and to take risks. If the culture of the organization is innovative and risk taking then employees will be more encouraged towards their work. They must have ability to adopt new things in the market. It is says that more risk more profit. So, risk taking organizations are more successful and profitable. They trained their employees according to the culture of organization. When the organization is successful, their employees will become satisfy to works with that organization. Their main focus is towards their goal which is product development and innovation.

Company lives and breathes new product development and employees work behavior support that goal. This put a good impact on employee's behavior when they are trained according to the innovativeness in the market.

\subsection{Employee Commitment}

Bateman and Strasser (1984), quoted in their research paper that employee commitment means loyalty of the employee to the organization, it shows the willingness to e.g. put best effort for the benefit of the organization, it is the degree of goal and value creation between the organization and it employees, and this is the desire of employee remain with the organization. Patrick Owens (2006) shows the impact of training on organizational turnover. If highly committed, then they received high turnover, also having other favors attitude. (Heffernan and Flood, 2000), Daft (2000), organizational culture is basic element to achieve organizational goals. Richardo (2001) said that achieving organizational goals and objectives is known as organizational performance. So it's necessary to perform well to get better results. That shows high return if performance well when committed with organization (Denison, 1990).Performance based on value of commitment of employee. According to Saffold (1998), said that culture gives a shape to organization to perform work, cultural contribution is also so important for better achievements. According to the study of (Gallagher, 2008), performance of the employees is the reason for enhancement in net profit of the organization. Strong culture has almost considered a driven force to improve the performance of the employees. It enhances self-confidence and commitment of employees and reduces job stress and improves the ethical behavior of the employees.

H2: Organizational Commitment has also positive effect over job Satisfaction.

\subsection{Job Satisfaction}

Job satisfaction is very important topic regarding the organizational behavior of an organizational behavior and organizational management. According to Dawis and Lofquits (1984) "job satisfaction is evaluation of individual's assessment level that how the working environment fulfill their needs. The employees who are satisfied will work for the progress of an organization and make their organizational culture healthy (Lock, 1969). Some researchers said that the job satisfaction is very important for the motivation of employees (Rao, 2005). Some research says, that if employees are happy with their job then it is better for the productivity of organization so result is that the employee's commitment with the organization (Beutinbach and De Witt, 2005). If the employees show the positive attitude towards work it shows that they are satisfied with the job (Sekaran, 1989). Egan et al., 2004; Silverthorne, 2004 mention that job satisfaction has a positive impact on employee productivity and it is negatively associated with employee's turnover. According to the Kreis and Brockopp (1986) job satisfaction is related to self-actualization needs of employee fulfillment through organizational work. Many studies demonstrate the good relationship between the job satisfaction and customer satisfaction (e.g., Band, 1988; George, 1990).Many studies have given the different kinds of measurements regarding this relation as Brook (2000) has given the review about this positive relationship as financial success and the job satisfaction. Job satisfaction is a combination of psychological, physiological and environmental 
circumstances by which a person can admit that he is satisfied with his job (Hoppock 1935). Job satisfaction is an orientation that is very affective of a person's part towards the roles of work on which they are dominant now (Vroom, 1964). Job satisfaction is the process by which the people think about their job and about its different aspects (Spector).job satisfaction represents the behavior of individual where they do their work (Davis et al., 1985).Job satisfaction shows the zeal and happiness with the work of person. Job satisfaction is the basic thing that shows path towards recognition, salary, promotion, and the achievement of the goals that fulfill their desires.(Kaliski, 2007). People have the different behaviors about their job such as the various kinds of work they perform their colleague, supervisor and their salaries (George, et al. 2008). The job satisfaction demonstrates the perception of a person that job make able the material and psychological desire(Aziri, 2008).

H3: Job Satisfaction affects negatively on the Turnover rate

\subsection{Turnover Intentions}

Organizational culture impacts on employee's retention. If the culture is positive then the employees do not leave the job and will like to work with organization. If the organizational culture, is negative then it would cause the high rate of turnover. If the organizations look after he employees than the employees will definitely look after the organization to recognize the employee turnover problem there is a need to recognize that indeed we have turnover problem (Bill Pollock). There is much need to hire the people best suited to your organization (Brinkers\& Philips, 1996). A Successful manager is the person who will help his employees to find satisfaction in their work, and "satisfaction" is important to an employee's decision to stay or leave the organization. (Buckingham and Coffman, 1999; Kreisman, 2002; Kaye and Jordan- Evans, 1999). Many companies are now facing many problems such as their product quality is suffering, level of their customer satisfaction is dropping and many organizations are facing problems because their key person are leaving the organizations. (Ambrose, 1996; Caplan and Teese, 1997; Reichheld, 2001; Deal and Kennedy, 1999).Schwepker (2001) said that there is a positive and statistically significant relationship between leaving intentions and actual leaving behavior as it is described by many study. In other words, intention to leave a job is an immediate precursor to actually leaving. Lambert et al.(2001), stated in his study that employee turnover can be affected by the various measures of job satisfaction; it is also stated that, employee turnover can be a cause of low job satisfaction. A decrease in employees turnover shows increases in organizational performance and its reduce the cost attached with hiring, and retraining of new employee's, Egan et al.(2004). According to Silverthorne (2004), "turnover causes significant expense to an organization," e.g. costs of hiring anew employee and loss of experience employee's and low productivity.

H4: If Organizational Culture is strong then it will impact negatively to turn over rate.

\section{Theoretical Framework}

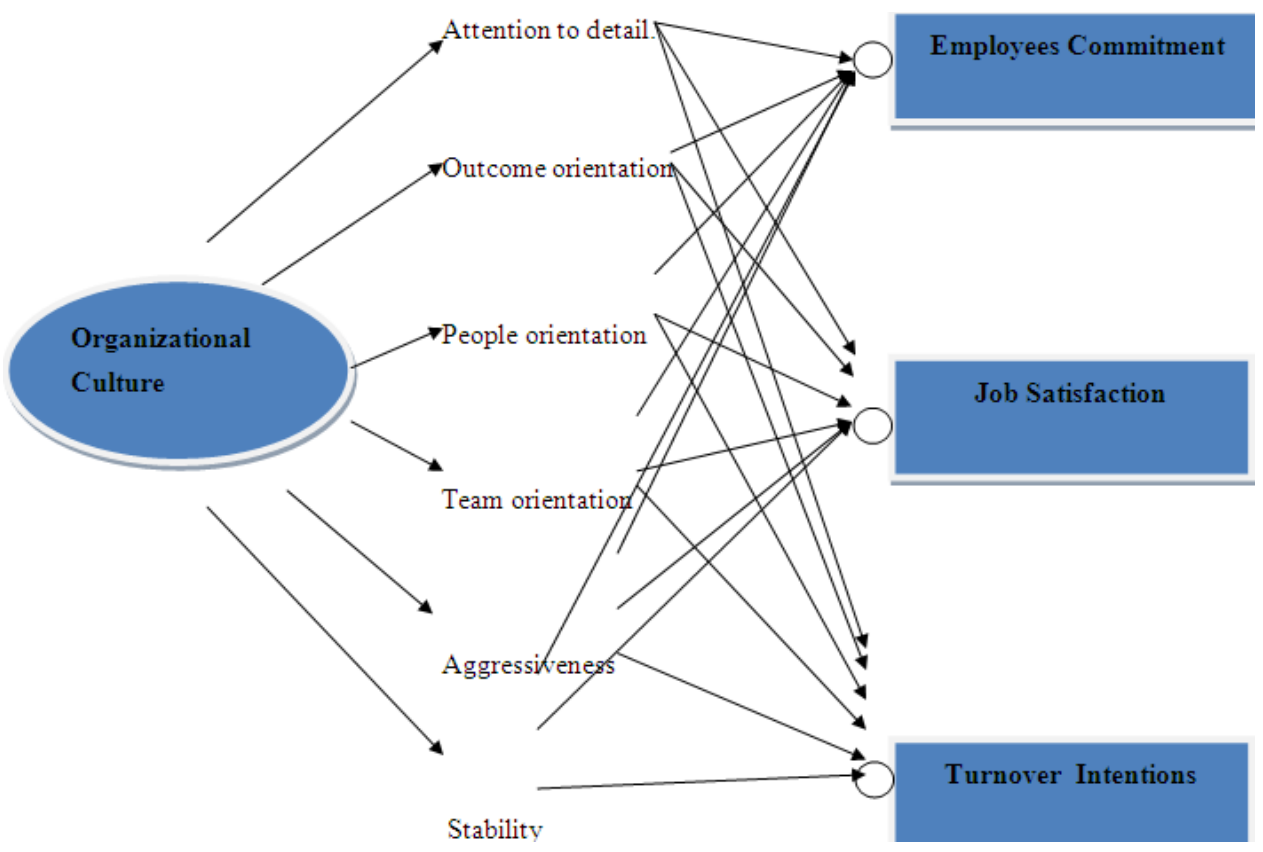




\section{Research Methodology}

\subsection{Participants}

Participants of this research paper were the employees of different organizations, like MCB Layyah, U micro Finance BankLayyah, Layyah Sugar Mill, Thermal Power Plant MuzaffarGarh, and NRSP DG Khan. Our target was the employees of different organizations in Southern Punjab of Pakistan.

\subsection{Instrument}

We used closed questionnaire having four research variables each variable contained six questions, so questionnaire was consisted of total 24 questions.

\subsection{Procedures}

We visited all these organizations and first of all we informed the respondents that all their information will keep confidential and then got the feedback directly from the respondents on the spot.

\subsection{Sampling}

We used random sampling design to select sample from population.

\subsection{Sample Size}

The Sample size of research was 235 respondents from which we collected data.

\subsection{Data Collection}

We used questionnaire which consists of 24-Questions of 4 variables of impact of organizational culture. We distributed 280 questionnaires and received 235 in complete form.

\subsection{Data Analysis}

Data collected from respondents was put into SPSS 19 and correlation analysis test was applied to revile the research results.

\section{Results and Discussions}

Table 6.1. Descriptive Statistics

\begin{tabular}{|c|c|c|c|}
\hline & Mean & Std. Deviation & N \\
\hline organizational_culture & 4.1678 & .58086 & 219 \\
\hline Employees_Commitment & 3.6306 & .52107 & 229 \\
\hline job_Satisfaction & 3.7253 & .56893 & 225 \\
\hline Employees_Retention & 3.7761 & .43366 & 222 \\
\hline
\end{tabular}

Table 6.2. Correlations

\begin{tabular}{|c|c|c|c|c|c|}
\hline \multirow{4}{*}{ organizational_culture } & & organizational_culture & Employees_Commitment & job_Satisfaction & Employees_Retention \\
\hline & $\begin{array}{l}\text { Pearson } \\
\text { Correlation }\end{array}$ & 1 & $.191^{* *}$ & $.268^{* *}$ & $.390^{* *}$ \\
\hline & Sig. (2-tailed) & & .005 & .000 & .000 \\
\hline & $\mathrm{N}$ & 219 & 214 & 211 & 208 \\
\hline \multirow{3}{*}{ Employees_Commitment } & $\begin{array}{c}\text { Pearson } \\
\text { Correlation }\end{array}$ & $.191^{* *}$ & 1 & $.627^{* *}$ & $.305^{* *}$ \\
\hline & Sig. (2-tailed) & .005 & & .000 & .000 \\
\hline & $\mathrm{N}$ & 214 & 229 & 223 & 218 \\
\hline \multirow{3}{*}{ job_Satisfaction } & $\begin{array}{l}\text { Pearson } \\
\text { Correlation }\end{array}$ & $.268^{* *}$ & $.627^{* *}$ & 1 & $.481^{* *}$ \\
\hline & Sig. (2-tailed) & .000 & .000 & & .000 \\
\hline & $\mathrm{N}$ & 211 & 223 & 225 & 215 \\
\hline \multirow{3}{*}{ Employees_Retention } & $\begin{array}{l}\text { Pearson } \\
\text { Correlation }\end{array}$ & $.390^{* *}$ & $.305^{* *}$ & $.481^{* *}$ & 1 \\
\hline & Sig. (2-tailed) & .000 & .000 & .000 & \\
\hline & $\mathrm{N}$ & 208 & 218 & 215 & 222 \\
\hline
\end{tabular}

**. Correlation is significant at the 0.01 level (2-tailed).

According to the above table we can easily describe the relationship among our variables. As we know that correlation exist between +1 to -1 . These two extreme point shows positive and negative correlation. According to the above table our significant level for correlation is $1 \%$ ( 0.01$)$, on the basis of that we will accept or reject our hypothesis. Table value of level of significance for Organizational Culture (Independent Variable) id .005, which is less than our significant level of correlation 0.01. While according to the given table, significant value of Employees Commitment, Employees Satisfaction and Turnover intention (Dependent Variables) is 0.00 . So $(0.00<0.01)$ shows there is positive relationship between job Satisfaction and its dependent variables 


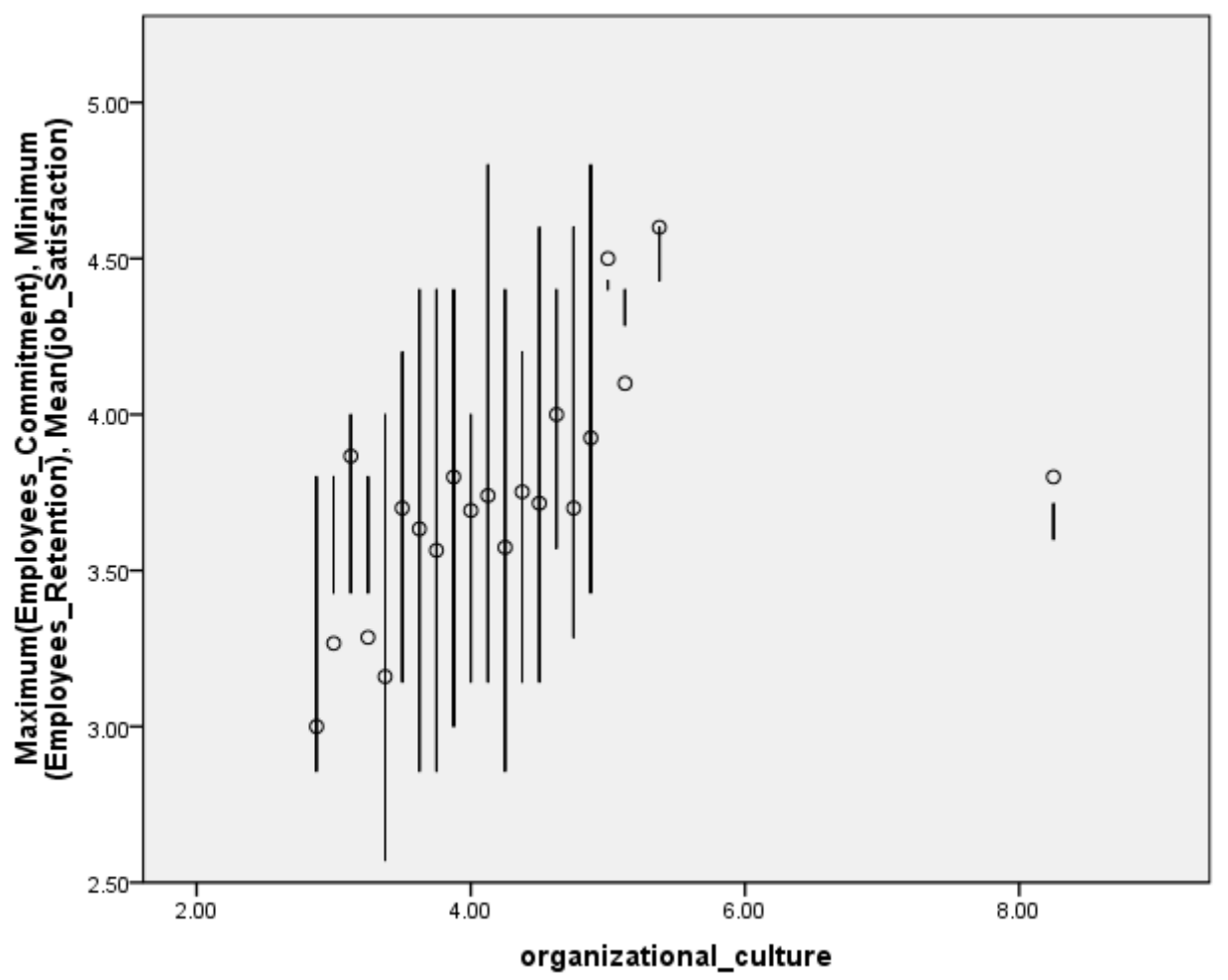

Figure 6.2.1

\section{Conclusions}

Every employee working in the organization has its own norms and values and different belief towards organization where he/she works. Sometimes organizational culture differs from employee norms and values so whenever any employee join the organization, he/she should allow herself that either they can come up with them or not. Organizational culture has strong and deep impact on the performance of the employees, that help employees to be satisfied themselves with organization and that cause to improve in the productivity of employee's. On the basis of findings of this research we conclude that there is positive and significant correlation among Impact of organizational culture on employees commitment, job satisfaction and employees retention. From our study we found that Organizational culture is important element which highly influences the employee commitment, job satisfaction and employees retention. As the organizational culture impacts positively or negatively on these three variables and considered as the base for performance of any organization. If the organizational culture is positive, it will enhance employee's commitment, job satisfaction and decrease employees' retention, automatically the performance will increase. It is quite easy to develop your organization in a positive way when any employee is on the right path. It is viewed in this study that strong organizational culture is very helpful for the new employees to adopt the organizational culture and to get the competitive advantage.

\section{Recommendations}

Organizational culture has strong and deep impact on the performance of the employees, that help employees to be satisfied themselves with organization and that cause to improve in the productivity of employee's. Organizational policies regarding culture should be clear for understanding the employees. Employee's behavior towards their work and organization are affected by organization policy and culture. Organization should have a flexible culture and top management should use decentralized technique of management so that employees at low level have authority and power to make decision regarding any problem they face according to their authority. Each and every employee must have direct dealing with the top level management. This thing will impact positively their satisfaction level as well as employees performance which will increase the organization productivity. Organization must provide the solution to the faculty member's problems first, because if any employee is facing problem at any stage and has some ambiguity regarding some operations, organization should have some clear policy to solve employee's issues, otherwise this thing create ambiguity in employees and will impact negatively their performance. There must be team work among the employees in organization it would enhance the performance of the employees.

\section{REFERENCES}


[1] Ambrose, Delores, (1996). Healing the downsized organization. New York: Three Rivers and Organizational Commitment on performance. Journal of Management

[2] Appealbaoum, S., Bartolomucii, No, Beaumier, E., Boulanger, J., Corrigan, r., Dore, I., Girard, C., \&Serroni, C. (2004). Organizational Citizenship behaviour a case study of culture, leadership and trust. Management Decision, 42 (1), $13-40$.

[3] Bill Pollock, White Paper, Employee Retention reducing recruitment by increasing retention.board after downsizing. Palo Alto, CA: Davies-Black Publishing.Brinkers and Phillips, (1969), Employee Retention, Reducing Recruitment by increasing retention.

[4] Buitenbach,J.H\& De-Witt,H.(2005). Job insecurity, extrinsic and intrinsic job satisfaction and affective organizational commitment of maintenance workers in parastatal. South African journal of Business Management, 36(2), 27-39.

[5] Bateman, T. and Strasser, S. (1984), "A longitudinal analysis of the antecedents of organizational commitment", Academy of Management Journal, Vol. 21, pp. 95-112

[6] Capplan, Gayle and Teese, Mary. (1997). Survivors-How to keep your best people on Chang S, and Lee MS, Learning Organization, 2007,14(02):155-185.

[7] Dawis,R.\&Lofquist,L.(1984).a psychological theory of work adjustment. Minneapolis, MN: University of Minnesota Press.

[8] Deal, Terrence and Kennedy, Allen. (1999). the new corporate cultures-Revitalizing the workplace after downsizing, mergers, and reengineering. Cambridge, MA: Perseus Books.

[9] Denison, D.R. (1990). Corporate Culture and Organisational Effectiveness. New York: Wiley. Development, 22 (8), 708708.

[10] Egan, T. M., Yang, B., \& Bartlett, K. R. (2004). The effects of organizational learning culture and job satisfaction on motivation to transfer learning and turnover intention. Human Resource Development Quarterly, 15(3), 279-301. doi:10.1002/hrdq. 1104

[11] Heery Edmund and Noon M (2001), A Dictionary of Human Resource Management, Oxford University Press, Pg 309

[12] Heffernan, M.M. \& Flood, P.C.(2000). An Exploration of the Relationship between Managerial Competencies Organizational, Characteristic and Performance in an Irish organization. Journal of European Industrial Training. University Press, 128-136

[13] Alfred A. Jaegar \& Rabindra Nath Kanungo (1990), Management in developing Countries,Kay, Beverly and Jordan-Evans. (1999). Love "em or lose 'em-Getting good people to Kreisman, Barbara J. (2002). Identification of the drivers of employee dissatisfaction and Lambert, E. G., Hogan, N.L., \& Barton, S. M. (2001). The impact of job satisfaction on turnover intent: a test of a structural measurement model using a national sample of workers. The Social Science Journal, 38(2), 233-250. doi:10.1016/S03623319(01)00110-0

[14] Lock,E.a(1969). What is job satisfaction? Organizational behavior and human performance,4,309-336.

[15] Lok, P. \& Crawford, J. (2004). The effect of Organizational
Culture and Leadership Style on Job Satisfaction and Organizational Commitment: A Cross National Comparison. Journal of Management Development, 23 (4), 321- 338.

[16] Lambert, E. G., Hogan, N.L., \& Barton, S. M. (2001). The impact of job satisfaction on turnover intent: a test of a structural measurement model using a national sample of workers. The Social Science Journal, 38(2), 233-250. doi:10.1016/S0362-3319(01)00110-0

[17] Lund, D. B. (2003). Organizational culture and job satisfaction. Journal of Business \& Industrial Marketing, 18(3), 219-236. doi: 10.1108/0885862031047313

[18] MacIntosh, E. W., \& Doherty, A. (2010). The influence of organizational culture on job satisfaction and intention to leave. Sport Management Review, 13(2), 106-117. doi:10.1016/j.smr.2009.04.006

[19] Meyer J. P., Allen, N. J., (1997) Commitment in the workplace: Theory, Research and Application. Thousand oaks: Sage Publication.

[20] O'Reilly CA, Chatman JA, and Caldwell DF, Acad Manage J, 1991, 34(3), 487-516Press.

[21] Rao,S.P.(2005) Essentials os HRM \& industrial Relationships,(480 to 482 ).

[22] Rashid, M. Z. A Sambasium M. \&Johari, J. (2003). The influence of Corporate Culture

[23] Reichheld, Frederick F. (2001). Loyalty rules! How today's leaders build lasting relationships. Boston, MA: Harvard Business School Press.

[24] Stephen P. Robbins (2009). Organizational Behavior, Pearson Education South Africa, 8th ed., 602-603

[25] Schneider B, and Reicher AE, Person Psych, 1983, 36: 19-37.

[26] Schwepker, C. H. (2001). Ethical climate's relationship to job satisfaction, organizational commitment, and turnover intention in the sales force, Journal of Business Research, 54(1), 39-52. doi: 10.1016/j.bbr.2011.03.031

[27] Seashore SE, and Taber TD, Am BehSci, 1975, 18(3), 333368 .

[28] Silverthorne, C. (2004). The impact of organizational culture and person-organization fit on organizational commitment and job satisfaction in Taiwan. Leadership \& Organization Development Journal, 25(7), 592-599. doi:10.1108/01437730410561477

[29] Sekaran ,U.(1989).paths to the job satisfaction of bank employees. journal of organizational behavior , 10(4),6-12.

[30] Sheridan J E (1992), Organizational Culture and Employee Retention, Academy of Management Journal, University of Chicago Press, Vol. 35, Pg 1036-1056

[31] Silverthorne, C. (2004). The Impact of Organizational Culture and Person-Organization fit on Organizational Commitment and job satisfaction in Taiwan. The Leadership and Organization. Development Journal, 25 (7), 592599.stay. San Francisco: Berrett-Koehler Publishers, Inc.turnover. Unpublished Doctoral Dissertation. Austin, TX: University of Texas.

[32] Aziri, B. (2008). Menaxhimi i burimeve njerëzore, Satisfaksioni ngapunadhemotivimii punëtorëve, Tringa 
Design, Gostivar, , p. 46

[33] Davis, K. and Nestrom, J.W. (1985). Human Behavior at work: Organizational Behavior, 7 edition, McGraw Hill, New York, p.109

[34] George, J.M. and Jones, G.R. (2008). Understanding and Managing Organizational behavior, Fifth Edition, Pearson/Prentice Hall, New Yersey, p. 78

[35] Hoppock, R. (1935). Job Satisfaction, Harper and Brothers, New York, p. 47

[36] Vroom, V.H. (1964). Work and motivation, John Wiley and Sons, New York, p.99
[37] Spector, P.E. (1997). Job satisfaction: Application, assessment, causes and consequences, Thousand Oaks,CA, Sage Publications, Inc

[38] Kaliski, B.S. (2007). Encyclopedia of Business and Finance, Second edition, Thompson Gale, Detroit, p. 446.

[39] Pettigrew, A. (1979). Studying organizational culture. Administrative Science Quarterly, 24, 570-581.

[40] Robbins, S. P. and Sanghi, S. (2007). Organizational Behavior, Pearson Education, New Delhi.

[41] Tichy, N. M. (1982). Managing Change Strategically: The Technical, Political, and Cultural Keys. Organizational Dynamics(autumn),pp. 59-80. 